\title{
ESSAY
}

\section{Finding Pathways to More Equitable and Meaningful Public-Scientist Partnerships}

\author{
Daniela Soleri*, Jonathan W. Long ${ }^{\dagger}$, Mónica D. Ramirez-Andreotta ${ }^{\ddagger}$, Rose Eitemiller ${ }^{\S}$ and \\ Rajul Pandyall
}

For many, citizen science is exciting because of the possibility for more diverse, equitable partnerships in scientific research with outcomes considered meaningful and useful by all, including public participants. This was the focus of a symposium we organized at the 2015 conference of the Citizen Science Association. Here we synthesize points made by symposium participants and our own reflections.

Professional science has a participation problem that is part of a larger equity problem in society. Inequity in science has negative consequences including a failure to address the needs and goals arising from diverse human and social experiences, for example, lack of attention to issues such as environmental contamination that disproportionately impact under-represented populations, and a failure to recognize the pervasive effects of structural racism. Inequity also encourages mistrust of science and scientists. A perception that science is practiced for the sole benefit of dominant social groups is reinforced when investigations of urgent community concerns such as hydraulic fracturing are questioned as being biased endeavors.

Defined broadly, citizen science can challenge and change this inequity and mistrust, but only if it reflects the diversity of publics, and if it doesn't reinforce existing inequities in science and society. Key will be the way that science is portrayed: Acknowledging the presence of bias in all scientific research and the tools available for minimizing this, and demonstrating the utility of science for local problem solving and policy change. Symposium participants called for reflexive research, mutual learning, and other methods for supporting more equitable engagement in practice and in the activities of the Citizen Science Association.

\begin{abstract}
Introduction
Reflecting much hard work and thought, the inaugural Citizen Science Association conference in San Jose, CA in February, 2015 (CSA 2015) manifested the excitement and promise increasingly felt about the evolving field of citizen science. A recent editorial in Nature (Nature 2015) further heralded the potential of this field to "generate data and to inform policy" by making "scientists of us all." That editorial also flagged potential downsides of the growth in citizen science, including concerns over data quality and the problem that non-professionals might introduce bias into research. What the editorial did not address was the importance of engagement and relevance to diverse and often underserved communities. Yet for many active in the
\end{abstract}

\footnotetext{
* Geography Department, UCSB, Santa Barbara, CA, USA

+ USDA Forest Service, Pacific Southwest Research Station, Davis, CA, USA

₹ Department of Soil, Water and Environmental Science, University of Arizona, Tucson, AZ, USA

$\S$ Community Coalition of Dewey-Humboldt, AZ, USA

" AGU Thriving Earth Exchange, Denver, CO, USA

Corresponding author: Daniela Soleri (soleri@geog.ucsb.edu)
}

field, the possibility of greater engagement and relevance is a significant part of the excitement of citizen science, that is, a commitment to pursuing more diverse, equitable partnerships in scientific research with outcomes that are considered meaningful and useful by all, including public participants. This possibility was the focus of a symposium that we, the coauthors of this paper and our colleague P. Iwasaki, organized together at CSA 2015. In this article we synthesize the points made by participants in the symposium with our own reflections and suggestions for better scientist-community partnerships and engagement of a broader public.

The symposium, Pathways to balance and partnership: Advancing equity, inclusion, and local relevance in citizen science, comprised a series of world café discussions ${ }^{1}$ among all participants (Fig. 1). World café exercises allow a large, diverse group of people to interact in the collective consideration of issues of importance to them. Clusters of people gather at different tables to discuss a question or questions for a short time, then redistribute themselves to new tables and new mixtures of tablemates to continue and revise the discussion. Rotating among tables allows people with different perspectives, knowledge, and values to interact in small group conversations that are 


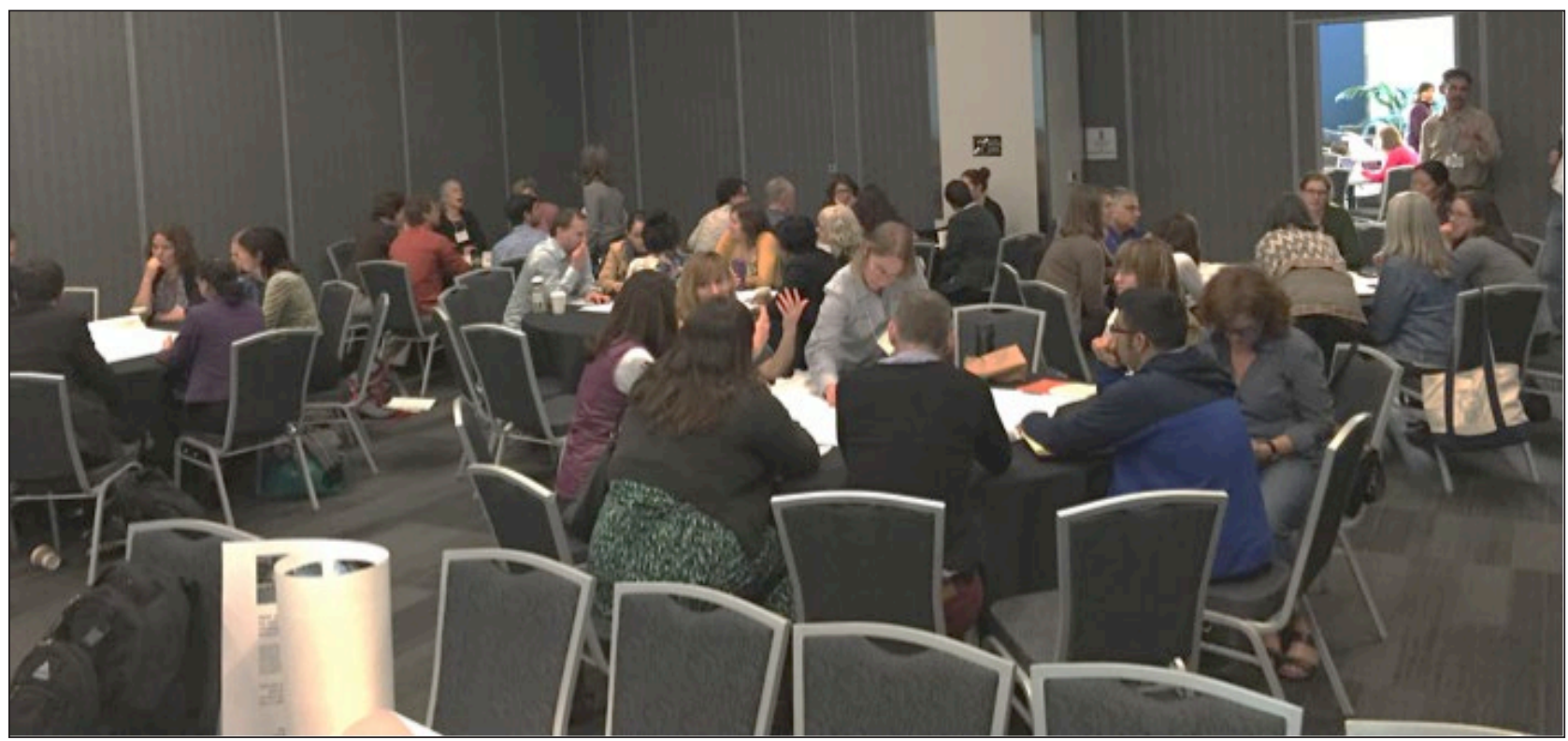

Figure 1: The Partnerships symposium world café in progress.

summarized at the end of the café. In the symposium, we discussed ways to make better partnerships, in terms of both process and outcome, between professional scientists (hereafter "scientists") and diverse publics or communities in citizen science.

A wide diversity of projects fall under "citizen science" or similar terms, and community participation in different projects may vary greatly (Ramirez-Andreotta et al. 2014, Shirk et al. 2012). Here we use the term "community" to emphasize public participation that to some degree is motivated by and experienced not only as an individual, but as a member of "a group of people with diverse characteristics who are linked by social ties, share common perspectives, and engage in joint action in geographical locations or settings" (MacQueen et al. 2001). Similarly, interpretation of the term "citizen" can range from membership in a group by virtue of participation in its social body, to strictly legal interpretations associated with specific territories, with the latter interpretations becoming increasingly divisive with migration of economic and political refugees. Early use of the term citizen science reflected both efforts to conduct science to better address the concerns of the public, as well as to cultivate engagement of everyday citizens in the process and understanding of science (Bonney et al. 2009, Irwin 1995, Riesch and Potter 2014). Here we focus on participation of "citizens" in science, while recognizing that emphasis on the term "citizen" may be counterproductive for both historical and contemporary reasons when trying to make science relevant and useful to more people. We also are cognizant that "participation" can be interpreted as engagement in research agendas established solely by scientists, but we use it here to represent engagement in all possible forms of partnerships to advance scientific understanding. Those partnerships can range from fairly conventional, scientist-driven research projects that have been extended to encourage community engagement, to crowdsourcing initiatives that depend on wide networks of members to collect data, to "co-created" projects that are often community driven and formulated to support communities' own research needs (Collman 2014, Shirk et al. 2012) (Fig. 2). While opportunities to enhance the quality of public engagement exist across this spectrum, in our symposium we focused on the community-driven

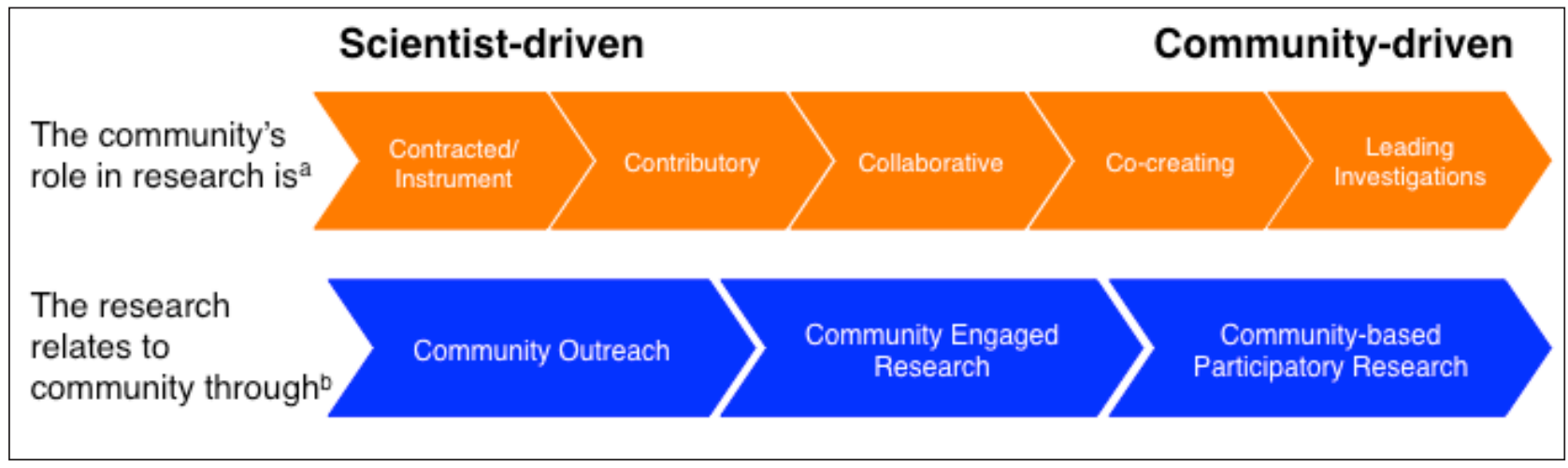

Figure 2: Examples of terminology commonly used to describe different forms of research partnerships between the public and professional scientists.

a Based on Shirk et al. 2012.

b Based on Collman 2014 
(Pandya 2014), co-created end as offering some of the greatest promise as well as greatest challenge for engagement with underserved communities (Pandya 2012). In this essay we provide a brief overview of the problem we were addressing and report the observations and suggestions made by symposium participants in the café.

\section{What's the problem?}

Professional science has a participation problem that is part of a larger equity problem in society. In the US, the composition of professional scientists does not represent the gender or racial composition of the population at large (NSF NCSES 2015), and remedying this discrepancy is the focus of a "bold new initiative" on the part of the National Science Foundation (NSF 2014). Increasing participation in professional science across all communities and groups in a population is a better use of human resources, as pointed out by the US NSF, but also could have promise for responding to the equity problem. Inequity in science has negative consequences and manifestations beyond the lack of diversity in the professional workforce. Such inequity leads to a failure to address the needs and goals that arise from diverse human and social experiences, for example, a lack of attention to issues such as environmental contamination that disproportionately impact under-represented populations, and a failure to recognize the wide-reaching effects of structural racism. Inequity also may encourage mistrust, skepticism, and unfamiliarity with science and scientists.

There is hope that citizen science might increase diversity in formal science and math fields when young people are attracted to science through experiences and interactions with scientists (Heggen et al. 2012). Citizen science also has the potential to increase the diversity of public participation in science overall and to enhance the opportunity for people to use science to solve problems in their communities and society (Mckinley et al. 2015). To realize its full potential, however, citizen science must reflect the diversity of communities and their concerns, and not reinforce existing inequities in science and society.

Today most citizen science participants are involved in scientist-driven, "contributory" projects as referred to by Shirk et al. (2012), many of which emphasize online databases or activities. Scientist-driven projects often target people who already have some advanced training, time, and resources, so that projects can more easily meet objectives for recruiting participants and obtaining high-quality data. Participants in contributory citizen science projects have motivations that are both altruistic (e.g., helping science, the environment, society), and self-serving (e.g., personal

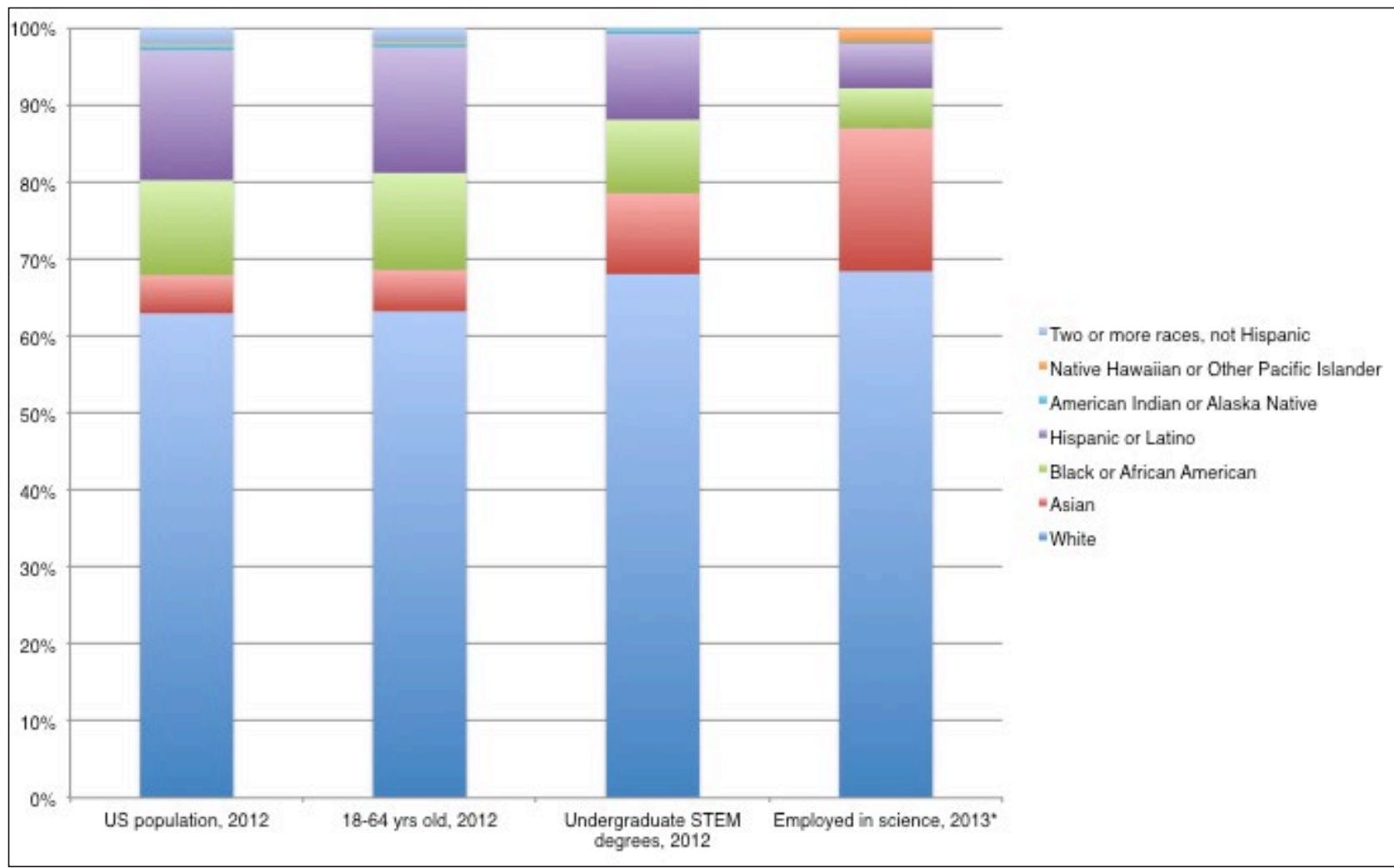

Figure 3: Demographic profile of US total and employment-aged population, STEM undergraduate degrees, and those with employment in science.

Sources: population- U.S. Census Bureau, 2012 Summary File, tables PCT12H-PCT12O; undergraduate STEM degreeshttp://www.nsf.gov/nsb/sei/edTool/data/college-14.html; science employment-National Science Foundation, National Center for Science and Engineering Statistics, Scientists and Engineers Statistical Data System (SESTAT), 2013, Table 11-1.

*Native Hawaiian and other Pacific Islander includes those reporting two or more races (non-Hispanic) for science occupation data. 
fulfillment, identity, learning, social connections) (Falk et al. 2007, Rotman et al. 2012, Raddick et al. 2009, Raddick et al. 2013). Such efforts have yielded valuable data, led to scientific discoveries, and brought more non-professionals into the research process (Bonney et al. 2015).

However, current citizen science participants do not reflect US demographics, with historically underserved populations continuing to be underrepresented (Pandya 2012). Although data are lacking, indications are that demographic profiles of citizen science participants reflect the imbalance among those pursuing higher education in the fields of Science, Technology, Engineering, and Math (Campbell 2002, Jolly 2002), and those in science professions (Fig. 3). Similarly, while racial minorities comprise about $38 \%$ of the US population, this group makes up only $16 \%$ of staff and board members of major US environmental NGOs, foundations, and government agencies (Taylor 2014). When asked how frequently they had collaborated with low-income groups in the last three years, more than $60 \%$ of environmental conservation and preservation organizations $(n=171)$ stated either "never" (40\%) or "seldom" (20\%).

For many citizen science projects, the average participant tends to be educated, older, middle and upper socioeconomic class, and white (Evans et al. 2005). For example, in the UK a recent thesis included a demographic profile of participants in the online project Garden Wildlife Health $(\mathrm{GWH})$, a collaboration between the Zoological Society of London and the British Trust for Ornithology (Maund 2014). Participants in GWH, who report sightings of sick or dead wildlife, were predominantly "whiteBritish," though not significantly different than the UK populations at large. However, participants include more females and more retired persons, who have more years of education and higher incomes than the larger population (Maund 2014).

But public involvement is influenced by the research being undertaken. Citizen science research designed to address environmental issues and possible injustices in people's daily lives can engage disenfranchised groups (e.g., Corburn 2005). For example, a preliminary inventory of the web presence of 130 active, environmentally oriented citizen science projects in northern California found that only $9 \%$ intentionally focused on communities of color (Ballard and Dixon 2013). However, a greater proportion of projects that were focused on communities of color used approaches to participation with substantial public engagement, as compared with all other projects inventoried (Table 1), a finding the authors suggested may be because they are "investigating environmental justice questions that involve communities of color disproportionately impacted by environmental problems" (Ballard and Dixon 2013).

In addition, some of the imbalance in who participates in citizen science can be attributed to how professionalized science is often practiced and portrayed. For many groups, science often seems distant, unhelpful, irrelevant, and even exploitative and unjust (Garrison 2013). Imbalances of power and breakdowns in trust often arise when members of the public perceive themselves as being kept uninformed and vulnerable (Jasanoff 1997, Jasanoff 2014).

A perception that science is practiced for the sole benefit of dominant groups in society is reinforced when efforts to investigate urgent community concerns are challenged. For example, the recent Nature editorial noted the potential for citizen science to generate biased findings, offering a hypothetical example that opponents of hydraulic fracturing (fracking) "might help track possible pollution because they want to gather evidence of harmful effects" (Nature 2015). While concern about motivation and bias is reasonable, these challenges are not unique to citizen science. Professional science is also vulnerable, as suggested by Nobel Prize-winning biologist Randy Schekman, who is boycotting Nature, Science, and Cell because he believes that those journals are corrupting the nature of scientific inquiry (Skinner et al. 2014) by providing "inappropriate incentives" such as impact factors and perceived prestige while unnecessarily limiting publication opportunities, resulting in an "escalating number of papers that are retracted as flawed or fraudulent" (Schekman 2013).

Indeed, the typical portrayal of science can fail to acknowledge the full range of influences that may be present in the scientific process. Scientists and institutions bring their own preconceptions, motivations, and biases, often in the form of implicit assumptions that are based upon their personal, professional, and social experiences. These assumptions are expressed when proposing research questions, collecting and interpreting data, and making recommendations (Costanza 2001, Cleveland 2014), and they may differ from the assumptions and interests of the affected public. These influences and assumptions mean that "science itself is an object of representation, and mis-representation, in a wide variety of

\begin{tabular}{|c|c|c|c|c|c|c|c|}
\hline \multirow[t]{3}{*}{ Project focus } & \multirow[t]{3}{*}{ Total number of projects } & \multicolumn{6}{|c|}{ Predominant approach to public participation in projects } \\
\hline & & \multicolumn{2}{|c|}{ Contributory } & \multicolumn{2}{|c|}{ Collaborative } & \multicolumn{2}{|c|}{ Co-created } \\
\hline & & $n$ & $\%$ & $n$ & $\%$ & $n$ & $\%$ \\
\hline Communities of color & 12 & 5 & $42 \%$ & 2 & $17 \%$ & 5 & $42 \%$ \\
\hline All others & 118 & 94 & $80 \%$ & 16 & $14 \%$ & 8 & $7 \%$ \\
\hline Total & 130 & 99 & $76 \%$ & 18 & $14 \%$ & 13 & $10 \%$ \\
\hline
\end{tabular}

Table 1: Forms of participation in environmental citizen science projects in northern California with a focus on communities of color compared with all projects surveyed.

Reproduced with permission from Ballard and Dixon 2013. 
settings" (Jasanoff 2014) (emphasis in original), as science studies scholar Sheila Jasanoff states in her essay "A mirror for science." She notes that understanding the diverse forces that shape how science is portrayed is important for improving relations between science and diverse public communities.

Without engaging a broad public that includes underserved communities, science is at risk of being misrepresented as irrelevant to the concerns and motivations of those communities and of reinforcing existing inequities. These risks are increased when communities are motivated by social or environmental justice concerns, which often are priorities. These motivations may be different than those typical in conventional science, or in some contributory citizen science projects, but different motivations do not mean the research they point to is biased. On the contrary, systemic bias often results from the failure to conduct research to address important concerns of underserved communities (Ottinger and Cohen 2012). Just as in professional science, citizen science avoids bias through replication of findings and open critiques.

Many participants in the pathways symposium expressed commitment to helping citizen science depart from historical, structural inequities that contribute to science's participation problem, and represent science as a tool relevant to questions that matter to all communities.

\section{How can we pursue more equitable partnerships?}

Broadening and deepening engagement of underrepresented communities in science is not a new idea, nor is scientific research dedicated to environmental justice, equity, and action. So what are known strategies that citizen science can use to create more equitable partnerships in research? Experience has shown that the questions asked, and the form of partnership and research approach used, are important. Asking questions that fail to address community concerns and using methods that exclude community participation can perpetuate the separation or boundary between professional scientists and members of the public, especially those who are disenfranchised (Ottinger 2010). In some cases environmental justice interests have overcome that boundary, transforming and improving science by demanding methods for investigating questions of community concern, and stimulating the creation of such methods that are adapting to changing technologies and hazards (Ottinger and Cohen 2012). Failing to involve the public and neglecting local knowledge can lead to deficits in science (Ottinger 2013) and in the translation of results (Ramirez-Andreotta et al. 2015a, Ramirez-Andreotta et al. 2015b).

Research approaches designed for greater equity are available. For example, community based participatory research (CBPR), which closely resembles co-created citizen science (Ramirez-Andreotta et al. 2014), is a research methodology in which power is distributed among community and scientist partners in all aspects of the scientific method to inform public health interventions, improve decision making, and/or stimulate action and policy changes (Minkler and Wallerstein 2008). CBPR intentionally spans both research and advocacy to successfully address complex environmental health challenges, and is good science (Brown 2013).

Community and scientist partnerships already have produced peer-reviewed publications, for example, regarding fracking consequences on local air quality at sites identified by community members and collected by them after protocol training (Macey et al. 2014). In a process that has been called "activism mobilizing science" (Conde 2014), local groups in Niger and Namibia have initiated and developed partnerships with scientists for monitoring uranium mine sites that had provided little accountability to local communities regarding radon hazards and safety precautions. Examples of evolving partnerships also can be seen in response to the current water quality crisis in Flint, Michigan, where academic scientists; health, social justice, and legal support NGOs; and community members are engaged in a short course (https://www.umflint.edu/ pubhealth/flint-water-crisis-course) focused on actionable information and "bi-directional learning" (Selig 2016), and Virginia Tech scientists and students, Flint residents, and others, are working together in the Flint water study (http://flintwaterstudy.org/).

Even beyond the questions asked and research process used, the data produced in diverse types of publicscientist partnerships can be used to either reinforce the boundary between scientists and the public or to bridge that boundary. The report-back and sharing of data with stakeholders and communities is crucial for shared action and is a way to overcome the distance between professional scientists and the public. This expanded role for research data means those data can be used in a variety of different ways while maintaining their integrity (Star and Griesemer 1989). For example, the data can be used by a professional scientist to test a hypothesis and by communities and/or activists to inform environmental policy reform and intervention (Brown 2013). These cases and many more have shown that science can be responsive, practical, and applied, while following the robust principles of the scientific method.

To ensure equity in research partnerships, it is important to consider how the products or findings of research may be used. For example, collecting data with community assistance, but without adequate informed consent regarding control of resulting products, can compound injustices experienced by under-represented groups (Colston et al. 2015, Drabiak-Syed 2010). Negative attitudes toward science may be reinforced when research findings fail to stimulate appropriate responses to community threats. Examples of lack of response to evidence of environmental threats in communities of color include the case of the Exide battery recycling plant in Los Angeles (Pulido 2015), and more recently the Flint water crisis (Hanna-Attisha et al. 2016).

Clearly research partnerships can be improved and made more equitable in many ways. Participants in our CSA 2015 symposium acknowledged this while giving particular emphasis to ways in which science and scientists can change to support equitable partnerships. They recognized that it is easy to forget that science occurs 
in a social context, not apart from it (Wynne 2014). As such, formal scientific training is not equivalent to objectivity, but rather a commitment to open self-reflection regarding assumptions and biases. As an example, reflexive research ethics, introduced by Cordner et al. (2012), refers to "the self-conscious, interactive, and iterative reflection upon researchers' relationships with research participants, relevant communities, and principles of professional and scientific conduct." A similar, self-reflective approach has been developed to enable scientists from different disciplines to collaborate (Eigenbrode et al. 2007), a challenge in many ways similar to public and professional scientist collaboration in that different motivations, assumptions, methods, values, and world views are at play. Drawing on these and other methods may be critical for helping citizen science avoid reinforcing existing historical and structural disparities in favor of more equitable partnerships.

During the café, symposium participants identified specific barriers to more equitable partnerships and suggested ways to remove them. In Table 2 we organized their observations into four categories: Association, observations or suggestions for what the CSA could do, or encourage; Journal and Conference, recommendations for those particular activities of the CSA; and Practice, advice for individuals or communities who participate in or lead citizen science programs. We have indicated those observations that refer to a reflexive research approach. We

Observations and recommendations

\section{Structure}

Decentralize with local or regional chapters

*Have teachers, community experts, youth leaders, and others be on advisory board, and members

*Make structure, decision-making transparent, open, and accessible

Topic based regional conferences

Have a monthly featured community scientist

\section{General resources}

CSA as central resource for how-to, and how NOT-to information.

*Analyses of models, practices that do and don't work

Need for awareness of existing programs and approaches to citizen science

Map all citizen science projects ( cit sci meta data). Hands on the Land.org mapping project for tracking projects and collaborating

*Connecting people regarding participatory action research (a good network for PAR researchers, including training, does not really exist, CSA could help provide that); see also publicscienceproject.org

Networking to help people connect (example of http://www.eecapacity.net/, supposed to be developing networking tools modeled after a

"dating site" to connect people to folks who might help with grant writing, community organizing); see Communication/bridging below Tools compendium online; e.g., CSA toolkit online at citizenscience.org; CitSci.org; other toolboxes

\section{Funding}

Crowdsource

Fee waivers, scholarships, outreach to remove barriers to diversity

\section{Training}

*Cultural competency (American Evaluation Assoc, http://www.eval.org/), ethics, humility training

*Best practices, models that work and why, reflexive practices

Training of trainers, training scientists to work with media

Adaptive management guidelines

Give the keynote address remote access online, also questions, comments submitted remotely

*Consider a community member or volunteer give keynote

\& Beware of duplication of speed and longer talks using up important conference time

Focus on one topic or theme with different perspectives all in same session. Don't make participation, inclusion a separate topic

* More environmental health and justice talks, these are issues of interest to a more diverse population

Lots of talk about diversity and inclusion, hard to see here (at CSA 2015 conference)!

Format could be more welcoming

$\ll$ Conference for volunteers

*Have more interactive, participatory sessions

*Involve, invite local communities more, provide support so they can come

Virtual conferences every other year?

\section{"Plain language" training, other eyes reviewers}

"Community reviewers, use feedback at each step in writing process

In publications: provide "in-a-nutshell," (or "implications for community members/leaders") summary to papers

$\leftarrow$ Make it accessible-Can lots of people get access (online, do people know about it)? Is the writing style accessible?

*Issue or theme based on reader ideas, community question

Annual issue or theme on diversity in citizen science 
Observations and recommendations

\section{Awareness of social context}

*Different values at individual, community, institutional, disciplinary levels

*Recognize different end games: understanding science, community engagement, community emancipation and rights

*Be aware of power relations within households and communities; e.g., gender dynamics

Community liaisons getting burned out, so address how to distribute the burden, and provide resources for this

"Who are community "leaders?" How to identify leaders, build capacity. Consider how identifying leaders can be problematic, leaders may equal gatekeepers for better or worse

\section{Communication/ bridging}

ڤ. Work with groups and people different than the usual ones

Lack of communication between different types of people or groups (i.e., community members, professional scientists, teachers, cultural leaders) and between similar types of groups (neighborhood centers, health NGOs, citizen science projects)

Create a "dating site" to identify non-traditional partners, e.g., outside of environmental groups

* Language used by scientists can exclude others, alienate nonscientists

Toolkits, mentors, directory, and map of projects to support new citizen science endeavors

*Communication among scientists

Communication integrated at all stages of research process

Nurture individuals who are honest liasons within and among groups

*Mutual trust and respect require time, shared experience; try breaking bread, productive hanging out

Meet ups for "volunteers" (so they go beyond their role in "our" projects), but should we go there (to their meetups)?

Connect with teachers through district level PDs, teacher advisory boards, NGSS alignment guides for curriculum

\section{${ }^{*}$ Cultural change in science}

Scientists need to consider commitments beyond professional advancement; humility training, separating self as human being from professional ego, don't be defensive

Recognize and consider values of communities and scientists; develop ethical strategies when these differ

Make long term commitments with communities where working, they are more than your "project site"

Science and partnerships require cultural competency

Use multidisciplinary approaches

Convince scientists that citizen science is real science; address scientists' fear of low data quality; what is science and who defines it and the data and methods that are acceptable, useful?

\section{Methods, quality}

Education is important but not central to citizen science mission

Decentralize support via online resources, regional groups

Engage and support teachers, mentors, facilitators, and others who can work with groups or students

Support project evaluation

Support, encourage social benefits for the public participants in projects

Research that contributes to public's scientific literacy

*How to identify leaders, build capacity (see above, Awareness of social context regarding leaders)

"Time and financial support needed to manage/coordinate the projects "for life"

] Constraints on teachers' time; provide lesson plans

음 *Funding for engagement, not just outreach

象 *More creative funding opportunities recognizing need for interdisciplinarity, partnerships, and long term engagement by all; removing

institutional, disciplinary barriers and territoriality

Need to build trust

Everyone (public, professional scientists, educators, policymakers) can feel their knowledge is not recognized or respected

Different or inaccessible language reinforces distance and barriers

L Lack of respect results in fear of speaking up, participating

When a scientist enters the room, conversation stops (expert on a pedestal)!

Who is asking the questions? Who believes the questions are important to them?

2 Asking questions where the community knows more - everyone contributes Education can be confounded with expertise

What is in a project for the community, for non-professional scientists?

Communities, individuals need to see value to them

Table 2: Compilation of observations from the CSA 2015 symposium Pathways to balance and partnership: advancing equity, inclusion, and local relevance in citizen science.

* Reflexive approach.

[CSA = Citizen Science Association; $\mathrm{CS}=$ citizen science; NGO = non-governmental organization $]$. 
hope that Table 2 and the following narrative can serve as a resource for CSA members and anyone considering engaging in citizen science.

\section{CSA-association}

Observations and recommendations regarding the CSA clustered around two themes. First, that the association should become a central resource for members, practitioners, and the public by providing access to networks, tools, methods, and other material, including how to apply a more reflexive approach. A specific recommendation was to provide connections to the methods and norms of Participatory Action Research (PAR), which emphasizes the need for reflexive practice and embodies a rich legacy of efforts to support community capacity and confront ethical issues in research (Greenwood and Levin 2006, Long et al. 2015). PAR and a variety of related approaches sprang from the popular education movement and work led by Paulo Freire (1970), Orlando Fals-Borda (1987), and others, which emphasizes inclusion of groups that will be impacted by an action in the problem-solving and solution-generating dialogue (Wiggins 2012, Freire 1970). To support such approaches, café participants suggested that the association could offer training for scientists especially in humility, ethics, and cultural competency (Quigley et al. 2015, Tervalon and MurrayGarcia 1998).

A second theme that emerged from café discussions regarding the association was that decentralization, in the form of regional or local groups and conferences, would provide a chance to engage more people from more diverse backgrounds, perspectives, and careers. To elicit new perspectives and question old assumptions it was suggested that community members be included in CSA decision-making bodies and that association governing processes be deliberately constructed to be transparent and accessible.

\section{CSA-conference}

Café participants' statements indicate their interest in modeling CSA conferences on the larger idea of closer scientist-community partnerships. Noting that CSA conference attendees were very similar to attendees at many other scientific conferences in the US, café participants recommended expanding conference participation by inviting and funding participation by members of local community groups. They suggested arranging sessions to promote opportunities for reflections on practice, for example, by intentionally integrating the multiple dimensions of research challenges facing particular communities and the scientists working with them. This approach would contrast with grouping sessions on participation and equity separately from those organized around particular issues or methods. Participants also suggested recruiting more sessions on community-driven issues that may be underemphasized in conventional research programs, such as environmental and health justice.

\section{CSA-journal}

Suggestions for how the CSA journal Citizen science: Theory and Practice could promote equity, and especially reflexivity, revolved around encouraging more community-defined content that could stimulate readers to consider new perspectives. Café participants felt that access to the journal is important and this includes not just open access online, but also content accessibility through clear, jargon-free writing and relevance to the public, especially the public involved in citizen science projects. This involves making space for nontraditional contributors, including high school and undergraduate students and community members, as well as encouraging researchers to present their findings in highly accessible language and with short "in a nutshell" summaries explaining the implications for communities. Along these lines, on its website Nature's Notebook (NN) provides brief, accessible "vignettes" (https://www.usanpn.org/nn/vignettes) of research published using the citizen science data submitted to $\mathrm{NN}$ for the US National Phenology Network. While this journal may not have been developed to serve the readership that café participants envisioned, their comments indicate that some CSA members see this as an important need.

\section{CS-practice}

The majority of observations in the symposium referred to more fundamental issues of practicing citizen or participatory science, and this was also the area with the most observations regarding the importance of reflexivity. Many of our discussions focused on how scientists and our institutions can build effective and long-lasting partnerships with communities who do not have access to customary science resources by changing our approach from a one-directional (traditional outreach) to a bi-directional (engagement and reflexivity) approach that recognizes the local knowledge and experiences of community partners. Other suggestions emphasized the need for reflection by researchers on their roles, assumptions, and practices. For example, patient and respectful listening and thoughtful review of implicit biases, assumptions, and ways of communicating are important for ensuring that research is both accessible and relevant to communities. Researchers can translate reflection into action by considering ways that they can support bottom-up, communitydriven projects rather than initiating research based on their own interests and questions. Various organizations such as the New England Environmental Justice Network (http://www.northeastern.edu/ejresearchnetwork/), Thriving Earth Exchange (http://thrivingearthexchange. org/), and EEcapacity (http://www.eecapacity.net/) have developed networking and educational tools to help communities find such researchers and other experts with specialized skills appropriate to their needs who are ready to work in respectful partnership.

Many participants lamented the separation between professional scientists and the public and suggested ways that science and scientists can better bridge that gap. These include making cultural changes to formal science 
and its reward systems to encourage more professional scientists to become involved in research partnerships with the public, re-evaluating what research quality means and how it should be assessed, being more inclusive of other forms of knowledge and expertise (Tengö et al. 2014), and being more aware of the social contexts of research both within and outside of scientific institutions.

\section{Conclusion}

Many participants in the symposium described in this essay view citizen science as an opportunity to go beyond inviting more members of the public to join scientists' research, and instead to rethink efforts to build a more equitable community of science and society. They indicated that an important step is to challenge assumptions that may reinforce distrust and separation between scientists and some members of the public, assumptions that can make science seem irrelevant to certain communities.

The observations from the world café reflect the fact that most of the symposium attendees were already concerned about the limitations of conventional scientific practice along with the need for greater critical reflection and actions to promote reform. Even beyond the symposium, many citizen science practitioners and attendees of CSA 2015 are cognizant of who is not "at the table," and they are looking for tangible ways to change that. They are aware that despite broad aims of making science accessible to all citizens of the world our newly formed association struggles to reflect the diversity of society, but they also believe that citizen science offers a theoretical and practical foundation to help scientists and communities bridge the divide between them.

Participants in this and several other symposia and open sessions on diversity, equity, and inclusion were energized by our positive collaboration and sharing of valuable insights. Symposium participants stated that they are eager for more opportunities to discuss these issues using an interactive format like the world café. This enthusiasm demonstrated the interest in helping our science and community institutions be more reflexive and change so that science will be more useful and relevant to different people and groups. Further, symposium participants had practical suggestions for making that change. They noted that more and more communities and individuals are not waiting for an invitation but are expecting greater control when developing partnerships to investigate questions that are important to them.

The CSA can assume a leadership role in broadening the relevance of and engagement in science through a more balanced representation of science, and by deepening the quality of partnerships with under-represented communities. Citizen science may now be strong enough, and a sufficiently large umbrella for different forms of participatory research, that it can leverage changes in the institutional incentive and funding structures in ways that better recognize the value and time required to develop trustworthy, respectful, and effective partnerships. We look forward to helping the CSA play a vital role in that transformation and continuing these discussions, including at the next conference in 2017.

\section{Note \\ ${ }^{1}$ www.theworldcafe.com/method.html}

\section{Acknowledgements}

We thank the participants in the CSA 2015 symposium "Pathways to balance and partnership: advancing equity, inclusion, and local relevance in citizen science" for their enthusiasm and suggestions that we report here; Patti Iwasaki, our colleague in organizing and conducting the symposium; Jennifer Carrera, Tim Vargo, and Anna Zivian, who volunteered to serve as additional anchor participants during the world café; and two anonymous reviewers and the editors, all of whose comments improved this essay.

\section{Competing Interests}

The authors declare that they have no competing interests.

\section{References}

Ballard, H.L. and Dixon, C., 2013. Learning from public participation in scientific research (PPSR) programs in northern California. Davis, CA: UCD School of Education.

Bonney, R., Cooper, C.B., Dickinson, J., Kelling, S., Phillips, T., Rosenberg, K.V. and Shirk, J., 2009. Citizen science: a developing tool for expanding science knowledge and scientific literacy. BioScience, 59: 977-984. ISSN (printed): 0006-3568.

Bonney, R., Phillips, T.B., Ballard, H.L. and Enck, J.W., 2015. Can citizen science enhance public understanding of science? Public Understanding of Science. ISSN (printed): 0963-6625. DOI: http://dx.doi.org/ $10.1177 / 0963662515607406$

Brown, P., 2013. Integrating medical and environmental sociology with environmental health crossing boundaries and building connections through advocacy. Journal of Health and Social Behavior, 54: 145-164. DOI: http:// dx.doi.org/10.1177/0022146513484473

Cleveland, D.A., 2014. Balancing on a Planet: The future of food and agriculture. Berkeley: University of California Press. ISBN: 9780520277427.

Collman, G.W. 2014. Community-based approaches to environmental health research around the globe. Reviews on Environmental Health, 29: 125-128. DOI: http://dx.doi.org/10.1515/reveh-2014-0030

Colston, N.M., Vadjunec, J.M. and Wakeford, T., 2015. Exploring the entry points for citizen science in urban sustainability initiatives. Current Opinion in Environmental Sustainability, 17: 66-71. ISSN (printed): 1877-3435.

Conde, M., 2014, Activism mobilising science. Ecological Economics, 105: 67-77. DOI: http://dx.doi.org/10.1016/ j.ecolecon.2014.05.012

Corburn, J., 2005. Street science: Community knowledge and environmental health justice. Cambridge, MA: The MIT Press. ISBN: 026203333X. 
Cordner, A., Ciplet, D., Brown, P. and Morello-Frosch, R., 2012. Reflexive research ethics for environmental health and justice: Academics and movement building. Social Movement Studies, 11: 161-176. DOI: http:// dx.doi.org/10.1080/14742837.2012.664898

Costanza, R., 2001. Visions, values, valuation, and the need for ecological economics. BioScience, 51: 459-468. DOI: http://dx.doi.org/10.1641/0006-3568(2001) 051[0459:VVVATN]2.0.CO;2

Drabiak-Syed, K., 2010. Lessons from Havasupai tribe v. Arizona state university board of regents: Recognizing group, cultural, and dignity harms as legitimate risks warranting integration into research practice. Journal of Health and Biomedical Law, 6: 175-225.

Eigenbrode, S.D., O'rourke, M., Wulfhorst, J.D., Althoff, D.M., Goldberg, C.S., Merrill, K., Morse, W., Nielsen-Pincus, M., Stephens, J., Winowiecki, L. and Bosque-Perez, N.A., 2007. Employing philosophical dialogue in collaborative science. BioScience, 57: 55-64. DOI: http://dx.doi. org/10.1641/b570109

Evans, C., Abrams, E., Reitsma, R., Roux, K., Salmonsen, L. and Marra, P.P., 2005. The Neighborhood Nestwatch Program: Participant outcomes of a citizen science ecological research project. Conservation Biology, 19: 589-594. DOI: http://dx.doi.org/10.1111/j.15231739.2005.00s01.x

Falk, J.H., Storksdieck, M. and Dierking, L.D., 2007. Investigating public science interest and understanding: Evidence for the importance of free-choice learning. Public Understanding of Science, 16: 455-469. DOI: http://dx.doi.org/10.1177/0963662506064240

Fals-Borda, O., 1987. The application of participatory action-research in Latin America. International sociology, 2: 329-347. DOI: http://dx.doi.org/10.1177/ 026858098700200401

Freire, P., 1970. Pedagogy of the oppressed, New York: Herder and Herder.

Garrison, N.A., 2013. Genomic justice for Native Americans: Impact of the Havasupai case on genetic research. Science, Technology \& Human Values, 38: 201-223. DOI: http://dx.doi.org/10.1177/0162243912470009

Greenwood, D.J. and Levin, M., 2006. Introduction to action research: Social research for social change. SAGE publications. ISBN: 1483389375.

Hanna-Attisha, M., Lachance, J., Sadler, R.C. and Champney Schnepp, A., 2016. Elevated blood lead levels in children associated with the Flint drinking water crisis: A spatial analysis of risk and public health response. American journal of public health, 106: 283-290. DOI: http://dx.doi.org/10.2105/AJPH.2015.303003

Heggen, S., Omokaro, O. and Payton, J., 2012. Mad Science: Increasing engagement in STEM education through participatory sensing. Proc. of the Sixth International Conference on Mobile Ubiquitous Computing, Systems, Services and Technologies.

Irwin, A., 1995. Citizen science: A study of people, expertise and sustainable development. Psychology Press. ISBN: 0415130107.

Jasanoff, S., 1997. Civilization and madness: the great BSE scare of 1996. Public Understanding of Science, 6: 221-232. DOI: http://dx.doi.org/10.1088/0963-6625/6/3/002
Jasanoff, S., 2014. A mirror for science. Public Understanding of Science, 23: 21-26. DOI: http://dx.doi. org/10.1177/0963662513505509

Jolly, E.J., 2002. Confronting demographic denial: Retaining relevance in the new millennium. The Journal of Museum Education, 3-6. DOI: http://dx.doi.org/10.10 80/10598650.2002.11510461

Long, J.W., Ballard, H.L., Fisher, L.A. and Belsky, J.M., 2015. Questions that won't go away in participatory research. Society \& Natural Resources, 29: 1-14. DOI: http://dx.doi.org/10.1080/08941920.2015.1024368

Macey, G., Breech, R., Chernaik, M., Cox, C., Larson, D., Thomas, D. and Carpenter, D., 2014. Air concentrations of volatile compounds near oil and gas production: A community-based exploratory study. Environmental Health, 13: 82. DOI: http://dx.doi.org/10.1186/1476069X-13-82

MacQueen, K.M., Mclellan, E., Metzger, D.S., Kegeles, S., Strauss, R.P., Scotti, R., Blanchard, L. and Trotter, R.T., 2001. What is community? An evidence-based definition for participatory public health. American Journal of Public Health, 91: 1929-1938. DOI: http://dx.doi. org/10.2105/AJPH.91.12.1929

Maund, P., 2014. Understanding what motivates participation in environmental digital citizen science across different sectors of society in the United Kingdom. MSc, Imperial College London.

Mckinley, D., Miller-Rushing, A., Ballard, H., Bonney, R., Brown, H., Evans, D., French, R., Parrish, J., Phillips, T., Ryan, S., Shanley, L., Shirk, J., Stepenuck, K., Weltzin, J., Wiggins, A., Boyle, O., Briggs, R., Chapin, I.Sf., Hewitt, D., Preuss, P. and Soukup, M., 2015. Investing in citizen science can improve natural resource management and environmental protection. Issues in Ecology, 19: $1-28$.

Minkler, M. and Wallerstein, N. (eds.), 2008. Communitybased participatory research for health., San Francisco: Jossey-Bass.

Nature, 2015. Editorial: Rise of the citizen scientist. Nature, 524: 265.

NSF, 2014. Pathways to broadening participation in response to the CEOSE 2011-2012 recommendation. Arlington, VA: US National Science Foundation.

NSF NCSES, 2015. Women, minorities, and persons with disabilities in science and engineering: 2015. Arlington, VA: National Science Foundation, National Center for Science and Engineering Statistics.

Ottinger, G., 2010. Buckets of resistance: Standards and the effectiveness of citizen science. Science, Technology \& Human Values, 35: 244-270. DOI: http:// dx.doi.org/10.1177/0162243909337121

Ottinger, G., 2013. Refining expertise: How responsible engineers subvert environmental justice challenges. New York, NY: NYU Press. ISBN: 9780814762387. DOI: http://dx.doi.org/10.18574/nyu/9780814762370. 001.0001

Ottinger, G. and Cohen, B., 2012. Environmentally just transformations of expert cultures: Toward the theory and practice of a renewed science and engineering. Environmental Justice, 5: 158-163. DOI: http://dx.doi. org/10.1089/env.2010.0032 
Pandya, R.E., 2012. A framework for engaging diverse communities in citizen science in the US. Frontiers in Ecology and the Environment, 10: 314-317. DOI: http:// dx.doi.org/10.1890/120007

Pandya, R.E., 2014. Community-driven research in the Anthropocene. Future Earth-Advancing Civic Understanding of the Anthropocene. John Wiley \& Sons, Inc. DOI: http://dx.doi.org/10.1002/9781118854280.ch6

Pulido, L., 2015. Geographies of race and ethnicity 1 White supremacy vs white privilege in environmental racism research. Progress in Human Geography. ISSN (Printed): 0309-1325. DOI: http://dx.doi.org/10.1177/ 0309132514563008

Quigley, D., Sonnenfeld, D., Brown, P., Silka, L., He, L. and Tian, Q., 2015. Research ethics training on place-based communities and cultural groups. Journal of Environmental Studies and Sciences, 1-11. DOI: http://dx.doi. org/10.1007/s13412-015-0236-x

Raddick, M.J., Bracey, G., Gay, P.L.,Lintott,C.J.,Cardamone,C., Murray, P., Schawinski, K., Szalay, A.S. and Vandenberg, J., 2013. Galaxy Zoo: Motivations of citizen scientists. arXiv preprint arXiv:1303.6886.

Raddick, M.J., Bracey, G., Gay, P.L., Lintott, C.J., Murray, P., Schawinski, K., Szalay, A.S. and Vandenberg, J., 2009. Galaxy Zoo: Exploring the motivations of citizen science volunteers. arXiv preprint arXiv:0909.2925.

Ramirez-Andreotta, M.D., Brusseau, M.L., Artiola, J.F., Maier, R.M. and Gandolfi, A.J., 2014. Environmental research translation: Enhancing interactions with communities at contaminated sites. Science of the Total Environment, 497: 651-664. DOI: http://dx.doi. org/10.1016/j.scitotenv.2014.08.021

Ramirez-Andreotta, M.D., Brusseau, M.L., Artiola, J., Maier, R.M. and Gandolfi, A.J., 2015a. Building a co-created citizen science program with gardeners neighboring a superfund site: The Gardenroots case study. International Public Health Journal, 7. PMID: 25954473.

Ramirez-Andreotta, M.D., Lothrop, N., Wilkinson, S.T., Root, R.A., Artiola, J.F., Klimecki, W. and Loh, M., 2015b. Analyzing patterns of community interest at a legacy mining waste site to assess and inform environmental health literacy efforts. Journal of Environmental Studies and Sciences, 1-13. ISSN (Printed): 2190-6483

Riesch, H. and Potter, C., 2014. Citizen science as seen by scientists: Methodological, epistemological and ethical dimensions. Public Understanding of Science, 23: 107-120. DOI: http://dx.doi.org/10.1177/ 0963662513497324
Rotman, D., Preece, J., Hammock, J., Procita, K., Hansen, D., Parr, C., Lewis, D. and Jacobs, D., 2012. Dynamic changes in motivation in collaborative citizen-science projects. Proceedings of the ACM 2012 Conference on Computer Supported Cooperative Work, 2012. ACM, 217-226. DOI: http://dx.doi.org/10.1145/2145204.2145238

Schekman, R., 2013 (December 9). How journals like Nature, Cell and Science are damaging science. The Guardian.

Selig, S., 2016. To help resolve the Flint water crisis, a university leans on its community. The Conversation [Online]. Available from: http://tinyurl.com/selig2016.

Shirk, J.L., Ballard, H.L., Wilderman, C.C., Phillips, T., Wiggins, A., Jordan, R., Mccallie, E., Minarchek, M., Lewenstein, B.V. and Krasny, M.E., 2012. Public participation in scientific research: a framework for deliberate design. Ecology and Society, 17: 29. DOI: http://dx.doi. org/10.5751/ES-04705-170229

Skinner, N., Sapiña, L. and Gil, M., 2014. On Open Access, Impact Factors and boycotting the top science journals: An interview with Randy Schekman. Contributions to Science, 73-79. DOI: http://dx.doi. org/10.2436/20.7010.01.190

Star, S.L. and Griesemer, J.R., 1989. Institutional ecology, "translations" and boundary objects: Amateurs and professionals in Berkeley's Museum of Vertebrate Zoology, 1907-39. Social Studies of Science, 19: 387-420. DOI: http://dx.doi.org/10.1177/030631289019003001

Taylor, D.E., 2014. The state of diversity in environmental organizations. Ann Arbor, MI: Green 2.0.

Tengö, M., Brondizio, E.S., Elmqvist, T., Malmer, P. and Spierenburg, M., 2014. Connecting diverse knowledge systems for enhanced ecosystem governance: The multiple evidence base approach. Ambio, 43: 579-591. DOI: http://dx.doi.org/10.1007/s13280-014-0501-3

Tervalon, M. and Murray-Garcia, J., 1998. Cultural humility versus cultural competence: A critical distinction in defining physician training outcomes in multicultural education. Journal of Health Care for the Poor and Underserved, 9: 117-125. DOI: http://dx.doi.org/ 10.13533/hpu.2010.0233

Wiggins, N., 2012. Popular education for health promotion and community empowerment: A review of the literature. Health Promotion International, 27:356-371. DOI: http://dx.doi.org/10.1093/heapro/dar046

Wynne, B., 2014. Further disorientation in the hall of mirrors. Public Understanding of Science, 23: 60-70. DOI: http://dx.doi.org/10.1177/0963662513505397

How to cite this article: Soleri, D, Long, J W, Ramirez-Andreotta, M D, Eitemiller, R and Pandya, R 2016 Finding Pathways to More Equitable and Meaningful Public-Scientist Partnerships. Citizen Science: Theory and Practice, 1(1): 9, pp. 1-11, DOl: http:// dx.doi.org/10.5334/cstp.46

Submitted: 31 October 2015 Accepted: 10 April $2016 \quad$ Published: 20 May 2016

Copyright: ( $\odot 2016$ The Author(s). This is an open-access article distributed under the terms of the Creative Commons Attribution 4.0 International License (CC-BY 4.0), which permits unrestricted use, distribution, and reproduction in any medium, provided the original author and source are credited. See http://creativecommons.org/licenses/by/4.0/. 